\title{
An Empirical Study of the Relationship between the Ranking of America's Top States for Business and Unemployment Rate, Growth Rate of Employment, and Growth Rate of Gross State Product
}

\author{
Dr. Yun-Chen Morgan (Corresponding author) \\ Southeastern Louisiana University, Hammond, LA 70402, USA \\ E-mail:ymorgan@selu.edu
}

Dr. Yu Hsing

Southeastern Louisiana University, Hammond, LA 70402, USA

E-mail: yhsing@selu.edu

Dr. Antoinette S. Phillips

Southeastern Louisiana University, Hammond, LA 70402, USA

E-mail: antoinette.phillips@ selu.edu

Dr. Carl Phillips

Southeastern Louisiana University, Hammond, LA 70402, USA

E-mail: cphillips@selu.edu

Received: June 9, 2020 Accepted: July 8, 2020 Published: July 21, 2020

doi:10.5296/ber.v10i3.17384 URL: https://doi.org/10.5296/ber.v10i3.17384

\begin{abstract}
This study attempts to determine whether the ranking of America's top states for business by CNBC is correlated with state economic performance such as the unemployment rate, the growth rate of employment, and the growth rate of gross state product. Binary variables for
\end{abstract}


the South and the West are also considered. The sample consists of 50 states in 2018. The results indicate that the ranking of America's top states for business is correlated with each of these economic indicators. Regression analysis shows that the coefficient of the ranking in each of the three regressions is significant at the $1 \%$ level. A higher ranking for a state is associated with a lower unemployment rate, a higher growth rate of employment, and a higher growth rate of gross state product.

Keywords: Top states ranking, Unemployment rate, Growth rate of employment, Growth rate of gross state product

\section{Introduction}

In its widely watched program “America's Top States for Business 2018," CNBC (2018) reported that Texas, Washington, and Utah were ranked as the top three states whereas West Virginia, Mississippi, and Alaska were ranked as the bottom three states. Workforce, infrastructure, cost of doing business, economy, quality of life, technology and innovation, education, business friendliness, access to capital, and cost of living were the 10 criteria selected for the ranking. The first three factors were given more weight.

Texas has grown rapidly as a top-ranked state partly due to lack of personal and corporate income taxes. It has played an active and leading role in startups and venture capital investments. Many big companies have located in Texas. It ranked number one in business expansions and relocations for six consecutive years. It also ranked highest in the category of growth prospects. One weakness was its relatively low educational attainment among adult workers.

Washington, one of the least expensive states for energy costs, continued to be a main target state for venture capital investments, and has been the birthplace for big businesses such as Microsoft, Boeing, Amazon, Costco, Starbucks, Nordstrom, etc. It ranked very high in the quality and supply of labor, economic climate, and growth prospects.

Utah's energy costs were $15 \%$ less than the U.S. average. Its employment grew $3.3 \%$ annually in the last 5 years and ranked top in the U.S. The recent purchase of cloud unicorn Qualtrics by German SAP suggests its strengths in startups and tech community in Silicon Slopes. Its strengths included pro-business environment, less regulation, and supply and quality of labor.

Individual states have strived to improve their images and rankings of business environment in order to attract more businesses, increase job opportunities, generate more income, and raise more tax revenues. Businesses tend to prefer to choose states with adequate workforce, good infrastructure, low cost of doing business, strong economy, better quality of life, advanced technology and innovation, quality education, friendly business climate, easy access to capital, and low cost of living.

Information with respect to the ranking is very valuable for state policy makers to review and make policy changes to improve educational, economic, and other conditions. However, CNBC (2018) did not statistically link the ranking of America's top states for business to any 
economic indicators such as the unemployment rate, the growth rate of employment, and the growth rate of gross state product (state output).

This paper attempts to determine how these economic indicators would respond to changes in the ranking of best states for business. Data for the ranking of best states for business, the unemployment rate, the growth rate of employment, and the growth rate of gross state product for 50 states will be collected and analyzed. Regression analysis will be performed in order to quantify the relationship between the ranking of states for business and each of the three economic indicators. Estimated coefficients in the regression can be considered by state policy makers to evaluate the effect of an improvement in the ranking on each of the three economic indicators.

\section{Literature Survey}

Several recent studies examined the ranking of states for business and related subjects.

Forbes (2018) published its "Best States for Business 2018: Behind the Numbers" based on six criteria, namely, cost of doing business, labor supply, regulatory environment, the economy, growth prospects, and quality of life. North Carolina, Utah, and Texas were the top three ranked states whereas Maine, West Virginia, and Alaska were ranked as the bottom three states.

In its publication of the "10 Best States for Business," US News \& World Report (2019) ranked states based on patent creations, business birth rates, tax burden, number of Fortune 1000 company headquarters, and venture capital investments. California, Massachusetts, and Washington were ranked top three mainly because of the highest patent creations and venture capital investments.

In the article titled "Looking to start a business? These are the best and worst states for companies" published by USA Today (Stebbins \& Suneson, 2019), Massachusetts, Colorado, and Utah were ranked the top three. Massachusetts ranked relatively high in output growth, average earnings, adults with bachelor's degrees, venture capital deals, access to skilled labor force, etc. Colorado ranked relatively high in growth of output, adults with bachelor's degrees and venture capital deals. Colorado has had a rapid population growth, which would increase consumption spending, local business and economic growth. Utah is projected to have rapid population growth, leading to economic growth and a larger labor pool for business to select.

In its publication Chief Executive (2019), Texas, Florida, and Tennessee were ranked as the top three states for business and Illinois, New York, and California as the worst states. The criteria used in the ranking included taxes and regulation, the workforce, and the living environment.

These rankings of states for business varied to some degree partly due to the selection of different factors and assigning different weights to these factors.

Several recent articles examined the effects of state fiscal policy, education, environmental regulation, etc. on state economies. These factors, which were measured in different manners, were included in the ranking of states for business by CNBC, Forbes and Chief Executive. 
Chobanov and Mladenova (2009) revealed that the optimal government size measured by overall government spending was less than $25 \%$ of GDP and that optimal government consumption spending was $10.4 \%$ of GDP. The true numbers would be smaller than these thresholds because these results had an upward bias.

Gale, Krupkin, and Rueben (2015) reviewed the relationship between state tax cuts and economic growth. They showed that cuts on income taxes may lead to revenue decline and force severe spending cuts. When the sample period was extended beyond 2000, the relationship between economic growth and tax cuts was not stable in the long run. There was lack of evidence that tax cuts raised economic growth.

Frank and Garryyeva (2017) reviewed state tax policy and economic growth with a focus on North Carolina. They argued that income tax cuts should be matched with spending cuts or other revenues. In North Carolina, after tax cuts, sales and individual income tax collections rose, and lowering individual income tax rates did not result in less state revenue. North Carolina kept spending increase less than inflation and population growth. Economic growth rates increased after tax cuts were passed.

Norcross and Gonzalez (2018) estimated state fiscal solvency based on five dimensions. They found that Nebraska, South Dakota, Tennessee, Florida and Oklahoma were the top five most solvent states whereas Kentucky, Massachusetts, New Jersey, Connecticut, and Illinois were the bottom five states. Based on time series data, they showed that state budgets have not reached the pre-recession levels and that long-term liabilities rose substantially due to the Government Accounting Standards Board ruling requiring states to report unfunded pension liabilities.

Walczak, Drenkard, and Henchman (2018) developed a comprehensive state business tax climate index based on corporate income taxes, individual income taxes, sales taxes, property taxes, and unemployment insurance taxes. Wyoming, Alaska, South Dakota, Florida, and Montana were ranked as the best five states whereas New Jersey, California, New York, Connecticut, and Arkansas were ranked as the bottom five states. Lack of a major tax was a common reason for states ranked in the top 10. States with all types of taxes can still be ranked in the top 10. New Jersey ranked the lowest mainly due to one of the highest property taxes, the second highest corporate income tax, an inheritance tax, and one of the worst structured individual income taxes.

Blankenau, Simpson, and Tomljanovich (2007) showed that when public education spending rose 1 percentage point, economic growth would rise 0.201 percentage points. Decrease in distortionary tax rates caused growth rates to rise. The findings were conditional on the consideration of the crowding-out effect and incorporation of government budget constraint.

Jorgenson and Wilcoxen (1990) studied the effect of environmental regulation on U.S. economic growth. They found that emission controls took a great deal of resources of the economy and that the cost of pollution reduction was greater than $10 \%$ of total government spending.

Greenstone (2002) used the data from the Census of Manufactures to analyze the effect of the 
Clean Air Act. Factories with emitters of controlled pollution in nonattainment counties received more regulation than factories with emitters in attainment counties. During the enforcement period of 15 years, nonattainment counties lost $\$ 75$ billion of output, 590,000 jobs, and $\$ 37$ billion in capital stock.

Guo (2017) examined the relationship between health insurance policy and health care expenditures. He found a positive correlation between expenditures and coverage, as one would expect from standard insurance theory. In his sample estimation, he also found evidence of selection effect, which suggests that individuals who are in higher health risks will tend to prefer a more generous coverage.

\section{The Model}

Suppose that the ranking of best states for business would affect three economic indicators, namely, the unemployment rate, the growth rate of employment, and the growth rate of gross state product and that the North, the South and the West may exhibit different regional effects. The regressions to be estimated are:

$$
\begin{gathered}
U=\alpha_{1} R+\alpha_{2} S+\alpha_{3} W \\
E=\beta_{1} R+\beta_{2} S+\beta_{3} W \\
P=\gamma_{1} R+\gamma_{2} S+\gamma_{3} W
\end{gathered}
$$

where

$\mathrm{U}=$ the unemployment rate in a state,

$\mathrm{R}=$ the ranking of best states for business,

$\mathrm{E}=$ the growth rate of employment in a state,

$\mathrm{P}=$ the growth rate of gross state product in a state,

$\mathrm{S}=$ binary variable equal to one if a state is in the South, and

$\mathrm{W}=$ binary variable equal to one if a state is in the West.

Three hypotheses to be tested are the signs and significance of the ranking in each of the equations. Because a lower number indicates a higher ranking, the sign for $\mathrm{R}$ in each of the regressions is expected to be:

$$
\begin{aligned}
& \mathrm{H} 1: \alpha_{1}>0, \\
& \mathrm{H} 2: \beta_{1}<0, \\
& \mathrm{H} 3: \gamma_{1}<0 .
\end{aligned}
$$

These signs suggest that a higher ranking leads to a lower unemployment rate, a higher growth rate of employment, and a higher growth rate of gross state product. The sign for $\mathrm{S}$ or $\mathrm{W}$ depends on the region that a state belongs to. 


\section{Empirical Results}

The ranking of America's top states for business was collected from CNBC (2018). The choice of the CNBC data is mainly due to its more comprehensive coverage of the criteria making the ranking. The unemployment rate in 2018 and the growth rate of employment during 2017-2018 by state were collected from the U.S. Department of Labor. The data for the growth rate of gross state product during 2017-2018 were obtained from the Bureau of Economic Analysis, the U.S. Department of Commerce. The sample consists of 50 states. Washington, DC is not included in the sample due to lack of data for ranking.

An analysis of the sample shows that the average unemployment rate in the U.S. was $3.7760 \%$ in 2018 with Hawaii enjoying the lowest at 2.4\% and Alaska recording the highest at $6.6 \%$. The average employment growth rate in the U.S. was $1.0498 \%$ in 2017-2018 with Arizona experiencing the highest at $3.4255 \%$ and North Dakota logging the lowest at $-1.4255 \%$ mainly due to decrease in shale oil production. The average growth rate of gross state product in the U.S. was $2.1480 \%$ in 2018 with Washington state having the highest $5.7 \%$ and Alaska registering the lowest $-0.3 \%$. These statistics indicate that individual states may vary in unemployment rates, employment growth rates, and growth rates of gross state product.

Table 1 reports estimated regressions and related statistics. In the regression for the unemployment rate, $25.02 \%$ of the change in the dependent variable can be explained by the three explanatory variables. According to the F test, the test statistic is estimated to be 5.1172, which is greater than the critical value of 4.31 at the $1 \%$ level. Hence, all of the slope coefficients jointly are statistically different from zero at the $1 \%$ level. According to the test, the coefficient for the ranking is significant at the $1 \%$ level, and the binary variables for the South and the West are significant at the $10 \%$ and $2.5 \%$ levels, respectively. The regression without the binary variables refers to the Northern region. The estimated intercept suggests that the unemployment rate would be $2.9590 \%$ without the factors of the ranking and the regions. If a state lowers one ranking, the unemployment rate would increase by 0.0202 percentage points. Hence, if a state lowers the ranking by 10 , the unemployment rate would become $3.1610 \%$. If a state is in the South, the unemployment rate would increase by 0.4280 percentage points. If a state is in the West, the unemployment rate would rise by 0.6392 percentage points.

In the regression for the growth rate of employment, $35.56 \%$ of the variation in the dependent variable can be explained by the right-hand side variables with significant coefficients. The $\mathrm{F}$ test indicates that the all the slope coefficients jointly are significant at the $1 \%$ level. The coefficients for the ranking and the Southern and the Western regions are significant at the $1 \%$ or $5 \%$ level. The value of the intercept implies that state employment in the North would grow at an annual rate of $1.6101 \%$ without the factor of the ranking. If the ranking improves by one, the growth rate of employment would increase by 0.0388 . If a state improves the ranking by 10 , the growth rate of employment in a state would increase by 0.3880 percentage points. States in the South would increase the growth rate of employment by 0.6971 percentage points, and states in the West would increase the growth rate of employment by 0.7871 percentage points. 
In the regression for the growth rate of gross state product, the independent variables with significant coefficients can explain approximately $54.83 \%$ of the change in the dependent variable. The coefficients for the ranking and the West are significant at the $1 \%$ or $5 \%$ level whereas the positive coefficient for the South is insignificant at the $10 \%$ level. States in the North have a growth rate of gross state product of 3.1939\% without the factor of the ranking. When a state improves the ranking by one, the growth rate would increase by 0.0535 percentage points. States in the West increase the growth rate by 0.8376 percentage points.

Table 1. Estimated Regressions

\begin{tabular}{|l|l|l|l|}
\hline & Unemployment rate & $\begin{array}{l}\text { Growth rate } \\
\text { of employment }\end{array}$ & $\begin{array}{l}\text { Growth rate of gross } \\
\text { state product }\end{array}$ \\
\hline Intercept & $2.9590(0.0000)$ & $1.6101(0.0000)$ & $3.1939(0.0000)$ \\
\hline Ranking & $0.0202(0.0076)$ & $-0.0388(0.0001)$ & $-0.0535(0.0000)$ \\
\hline The South & $0.4280(0.0868)$ & $0.6971(0.0265)$ & $0.3033(0.1308)$ \\
\hline The West & $0.6392(0.0172)$ & $0.7871(0.0182)$ & $0.8376(0.0220)$ \\
\hline R-squared & 0.2502 & 0.3556 & 0.5483 \\
\hline F-statistic & $5.1172(0.0039)$ & $8.4597(0.0001)$ & $18.6161(0.0000)$ \\
\hline Sample period & 2018 & $2017-2018$ & $2017-2018$ \\
\hline Number of observations & 50 & 50 & 50 \\
\hline
\end{tabular}

Notes: Numbers in the parenthesis are probabilities. In the ranking, 1 represents the best state, and 50 represents the worst state.

\section{Summary and Conclusions}

This paper has examined the effects of the ranking of the best states for business on economic performance in terms of the unemployment rate, the growth rate of employment, and the growth rate of gross state product. Regional binary variables are included. The explanatory power ranges from $25.02 \%$ for the unemployment rate to $54.83 \%$ for the growth rate of gross state product. Empirical results show that the coefficient for the ranking of America's top states for business in each of the three regressions is significant at the $1 \%$ level.

A higher ranking reduces state unemployment rates, increases employment growth rates, and raises growth rates of gross state product. States in the South show higher unemployment rates and employment growth rates. States in the West exhibit higher unemployment rates, higher employment growth rates, and higher growth rates of gross state product.

The findings have several policy implications. State policy makers can estimate any changes in unemployment rates, employment growth rates and state output growth rates when their rankings improve. Once these changes can be quantified, proposed changes in the budget for unemployment insurance benefits, number of jobs created, income earned by workers, welfare benefits, etc. can be estimated more accurately. In trying to improve the ranking, state government officials may consider enhancing individual components. Any improvements in workforce, infrastructure, the economy, quality of life, technology and innovation, education, 
business friendliness, access to capital and reducing cost of doing business and cost of living would increase the overall ranking.

There may be areas for potential future research. The estimated values of R-squared suggest that in addition to the ranking, there may be other factors such as quality of education, workforce, and wages that may need to be considered. However, education, workforce, and cost of doing business have been included in making CNBC's overall ranking. Hence, including these variables may involve the double counting of these individual components.

There are other rankings of states for business environment. For example, Forbes published "Best States for Business 2018" (Forbes, 2018). It may be interesting to explore whether the ranking made by Forbes may show a similar correlation with one of the three economic indicators. The three regions could be divided into sub-regions in order to determine whether more detailed regional effects may be obtained.

\section{References}

Blankenau, W. F., Simpson, N. B., \& Tomljanovich, M. (2007). Public education expenditures, taxation, and growth: Linking data to theory. American Economic Review, 97(2), 393-397. https://doi.org/10.1257/aer.97.2.393

Chief Executive. (2019). 2019 Best \& Worst States for Business: An Overview. [Online] Available: https://chiefexecutive.net/2019-best-worst-for-states-business

Chobanov, D., \& Mladenova, A. (2009). What is the optimum size of government. Institute for Market Economics: Bulgaria, pp. 1-47.

CNBC. (2018). America's Top States for Business 2018: A scorecard on state economic climate. [Online] Available:

https://www.cnbc.com/2018/07/10/americas-top-states-for-business-2018.html

Forbes. (2018). Best States for Business 2018: Behind the numbers. [Online] Available: https://www.forbes.com/sites/kurtbadenhausen/2018/11/28/the-best-states-for-business-2018behind-the-numbers/\#7023f36e2bae

Frank, P., \& Garryyeva, L. (2017). State Tax Policy and Growth: Recent Evidence. The Jesse Helms Center. [Online] Available:

https://static1.squarespace.com/static/5a4e4b09a9db09ee8c3a75fe/t/5a849c99e4966b15dd83

7781/1518640283440/State+Tax+Policy+and+Growth+with+Executive+Summary.pdf

Gale, W., Krupkin, A., \& Rueben, K. (2015). The growth mirage: State tax cuts do not automatically lead to economic growth. Washington, DC: Urban-Brookings Tax Policy Center. [Online] Available:

http://www.taxpolicycenter.org/publications/growth-mirage-state-tax-cuts-do-not-automatical ly-leadeconomic-growth.

Greenstone, M. (2002). The impacts of environmental regulations on industrial activity: Evidence from the 1970 and 1977 clean air act amendments and the census of manufactures. Journal of political economy, 110(6), 1175-1219. 


\section{Macrothink}

Business and Economic Research

ISSN 2162-4860

2020, Vol. 10, No. 3

Guo, Z. (2017). Health Insurance and the Demand for Medical Care: A Case Study from China. Asian Journal of Economics and Empirical Research, 4(1) 8-13.

http://dx.doi.org/10.2139/ssrn.3011668

Jorgenson, D. W., \& Wilcoxen, P. J. (1990). Environmental regulation and US economic growth. The Rand Journal of Economics. 314-340. https://doi.org/10.2307/2555426

Norcross, E., \& Gonzalez, O. (2018). Ranking the states by fiscal condition. Mercatus Research Paper. https://doi.org/10.2139/ssrn.3381208

Stebbins, S., \& Suneson, G. (2019). Looking to start a business? These are the best and worst states for companies. USA Today. [Online] Available:

https://www.usatoday.com/story/money/business/2019/03/01/best-states-business-massachuse tts-tops-list-louisiana-worst/39094995/ (March 1, 2019).

U.S. News \& World Report (2019). 10 Best States for Business. [Online] Available:

https://www.usnews.com/news/best-states/slideshows/10-best-us-states-for-business

Walczak, J., Drenkard, S., \& Henchman, J. (2018). 2019 State Business Tax Climate Index. Tax Foundation.

\section{Copyright Disclaimer}

Copyright for this article is retained by the author(s), with first publication rights granted to the journal.

This is an open-access article distributed under the terms and conditions of the Creative Commons Attribution license (http://creativecommons.org/licenses/by/4.0/). 